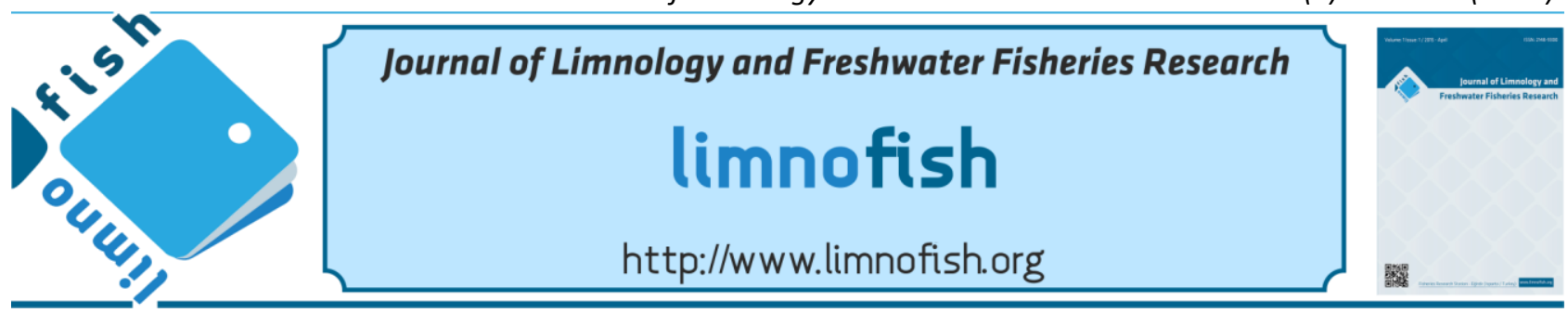

\title{
In Vitro Storage of Unfertilized Eggs of Scaly Carp (Cyprinus carpio) : Effect of Different Artificial Mediums and Storage Periods
}

\author{
Yusuf BOZKURT \\ İskenderun Technical University, Faculty of Marine Sciences and Technology Department of Aquaculture, İskenderun, Hatay, \\ Turkey
}

\section{A B STRACT}

The present study was carried out in order to explore the effect of different artificial mediums and in vitro storage periods on fertilization, eyeing and hatching success of scaly carp (Cyprinus carpio) eggs. The batches of about 200 pooled eggs treated with 20-ml three different extenders (Ringer, Dettlaff and Cortland) and Ovarian fluid in $15-\mathrm{cm}$ petri dishes, were stored at $22.5^{\circ} \mathrm{C}$ for 30 , 60 , or $90 \mathrm{~min}$. The in vitro stored eggs were fertilized by adding of $50 \mu \mathrm{lsperm}$ which showing motility higher than $80 \%$, in each petri dishes end of the storage period. The highest fertilization rates were determined as $86 \%$ and $72 \%$ with the egg samples stored for $60 \mathrm{~min}$ in Cortland solution and for $90 \mathrm{~min}$ in Ovarian fluid respectively $(\mathrm{p}<0.05)$. The highest eyeing rate $(80 \%)$ was determined in egg samples kept in Cortland solution for 60 min storage $(\mathrm{p}<0.05)$. Despite the best hatching rate $(60 \%)$ of the egg samples determined with Ovarian fluid at $30 \mathrm{~min}$ storage, the Cortland solution was $(48 \%)$ the best for $90 \mathrm{~min}(\mathrm{p}<0.05)$. Results indicate that Cortland solution is the most suitable extender and can be substituted instead of Ovarian fluid for in vitro storage of scaly carp eggs.

\section{ARTICLE INFO}

\section{RESEARCH ARTICLE}

Received : 06.12 .2018

Revised : : 10.03.2019

Accepted : : 18.03.2019

Published : :25.12.2019

DOI:10.17216/LimnoFish.492989

\section{* CORRESPONDING AUTHOR}

yusuf.bozkurt@iste.edu.tr

Phone : +903266141693

Keywords: Extender, egg, short-term preservation, fertilization

Döllenmemiş Pullu Sazan (Cyprinus carpio) Yumurtalarının In Vitro Muhafaza Edilmesi: Sulandırıcı ve Muhafaza Sürelerinin Etkisi

Öz: Bu çalışma, farklı sulandırıcı ve in vitro muhafaza sürelerinin pullu sazan (Cyprinus carpio) yumurtalarının döllenme, gözlenme ve açılma başarısı üzerine olan etkilerinin araştırılması amacıyla yürütülmüştür. 20-ml hacmindeki üç farklı sulandırıcı (Ringer, Dettlaff ve Cortland) ve ovaryum sıvısı ile $15-\mathrm{cm}$ çaplı petri kutularında muamele edilen yaklaşık 200 yumurta, $22.5^{\circ} \mathrm{C}^{\prime} \mathrm{de} 30,60$ ve $90 \mathrm{dk}$ süre ile muhafaza edildi. Ín vitro muhafaza edilen yumurtalar, muhafaza süresinin sonunda \% 80 'den fazla motil özelliğe sahip olan $50 \mu \mathrm{l}$ sperma ile her petri kutusunda döllenmiştir. En yüksek fertilizasyon oranları, Cortland solüsyonunda $60 \mathrm{dk}$ ve ovaryum sıvısında $90 \mathrm{dk}$ muhafaza edilen yumurta örneklerinde sirasıyla $\% 86$ ve $\% 72$ olarak belirlenmiştir $(\mathrm{p}<0,05)$. En yüksek gözlenme oranı Cortland solüsyonunda $60 \mathrm{dk}$ muhafaza edilen yumurta örneklerinde \%80 olarak belirlenmiştir $(\mathrm{p}<0,05)$. En iyi açılma oranı ovaryum sıvısında $30 \mathrm{dk}$ muhafaza edilen yumurta örneklerinde $\% 60$ olarak belirlenmesine rağmen, $90 \mathrm{dk}$ muhafaza süresinde ise en iyi sonuç Cortland solüsyonunda $\% 48$ olarak elde edildi $(\mathrm{p}<0,05)$. Elde edilen sonuçlar, Cortland solüsyonunun en iyi sulandırıcı olduğunu ve pullu sazan yumurtalarının in vitro muhafazasında ovaryum sıvısı yerine ikame edilebileceğini göstermektedir.

Anahtar kelimeler: Sulandırıcı, yumurta, kısa süreli muhafaza, döllenme

How to Cite

Bozkurt Y. 2019. In Vitro Storage of Unfertilized Eggs of Scaly Carp (Cyprinus carpio) : Effect of Different Artificial Mediums and Storage Periods. LimnoFish. 5(3): 181-186. doi: 10.17216/LimnoFish.492989

\section{Introduction}

Conservation of gametes in the cold or frozen state is an important biotechnological tool and has great concern for aquaculture. Growing attention to this biotechnology has guided an increasing number of researches in this field (Carolsfeld et al. 2003; Tiersch 2011).
The long-term conservation of fish sperm has been widely explored and optimized with cryopreservation techniques. Nowadays, it is possible using cryopreserved sperm in artificial propagation applications in aquaculture. On the other hand, similar methods regarding the conservation of eggs have not resulted in satisfactory results due to the 
difficulty of removing intercellular water during the cooling process in the cells (Stoss 1983).

Mature eggs may be retained for weeks until ovulation. Ovulated eggs retained in the ovarian cavity are exposed to overripening because of morphological and biochemical modifications affecting gamete and fertility quality negatively (Formacion et al. 1993). Nevertheless, time for storage is still available for effective using of ovulated eggs. Thus, prolonging of egg viability is an important issue in term of aquaculture practices (Rothbard et al. 1996).

The ovulated eggs should be fertilized within a certain period of time following the ovulation process in order to obtain viable embryos (Hobby and Pankhurst 1997). The important issue to be known that fertilization of ovulated eggs progressively decreases and then disappears when they are kept in the body cavity of the female for a long time. On the other hand, it is possible maintaining of fertility much longer for the eggs preserved in saline or coelomic solutions (Dettlaff et al. 1993). Conservation of fish eggs diluted with a suitable extender has many applications such as transporting of the gametes to other hatcheries in order to synchronize artificial propagation operations and chromosome manipulations (Suquet et al. 1999). Therefore, the establishment of an effective protocol is an important issue in terms of commercial aquaculture.

From this point of view, the current study was designed to explore the effect of different extenders and storage periods on fertility, eyeing and hatching success of scaly carp eggs following in vitro storage under culture conditions.

\section{Materials and Methods \\ Broodstock management and collection of gametes}

Mature male and female scaly carp broodfish which are suitable for the artificial propagation (+3 years of age), were selected in their natural spawning season from large soil ponds and were kept separately according to their sex in the hatchery. The broodfish which kept in 500-1 holding tanks supported with a water flow of $0.21 / \mathrm{s}$ at $24^{\circ} \mathrm{C}$ containing 6-7 mg/l dissolved $\mathrm{O}_{2}$, were fed with commercial feed ( $22 \%$ crude protein) at $1.5 \%$ ratio of body weight per day. Experiments were performed with 15 females $(42.6 \pm 4.5 \mathrm{~cm}$ total length, $1.2 \pm 0.4 \mathrm{~kg}$ body weight) and three males $(46.8 \pm 2.4 \mathrm{~cm}$ total length, $1.1 \pm 0.5 \mathrm{~kg}$ body weight) during the peak (May) of the reproductive period.

Females with a large, soft abdomen, red urogenital papilla, and males appearing sperm with slight abdominal pressure were assumed to be ready for the hormone treatment. Commercially available carp pituitary extract (CPE) was used as spawning agent. In order to induce spawning, CPE in Ringer solution was applied intramuscularly to the females in two portions as the priming and releasing doses ( 0.5 and $2.0 \mathrm{mg} / \mathrm{kg}$ body weight respectively) with a 14-h interval between doses. Males received a single dose of CPE $(1.0 \mathrm{mg} / \mathrm{kg}$ body weight $)$ intramuscularly at the time of the second dose was applied to the females (Bozkurt and Yavas 2012).

$100 \mathrm{mg} / \mathrm{L}$ quinaldine sulfate was applied to the broodfish for anesthetization and stripped via gentle abdominal massage. Eggs, Ovarian fluid, and sperm were collected separately from each female and male broodfish. Contamination of gametes with urine, mucus, blood or feces was avoided during the collection of gametes. The Ovarian fluid separated by pouring the eggs onto a screen suspended over a plate was used for storage purposes.

Sperm samples collected from three males into $50-\mathrm{ml}$ glass beakers were checked in term of motility at the end of each storage period. Samples showing more than $80 \%$ motility, were pooled in a $100-\mathrm{ml}$ glass beaker. Fresh sperm was placed in a refrigerator $\left(+4^{\circ} \mathrm{C}\right)$ to prevent deformation for a few minutes until used fertilization of the pooled eggs.

\section{Evaluation of spermatoa motility and density}

$10 \mu 1$ drops of sperm were placed on a microscope slide and $20 \mu \mathrm{l}$ activation solution $(0.3 \% \mathrm{NaCl})$ was added. Sperm suspension was thoroughly mixed and spermatozoa motility was evaluated in terms of progressive forward movement using light microscope (Olympus, Japan) with an x400 magnification. The motility percentages were defined as the percentage of spermatozoa moving in a forward motion every $20 \%$ motile increment (i.e., 0, 20\%, 40\%, 60\%, 80\%, and 100\%) (Vuthiphandchai and Zohar 1999).

For the purpose of evaluation of spermatozoa density, sperm was diluted at a ratio of 1:1000 with Hayem solution $\left(5 \mathrm{~g} \mathrm{Na}_{2} \mathrm{SO}_{4}, 1 \mathrm{~g} \mathrm{NaCl}, 0.5 \mathrm{~g} \mathrm{HgCl}_{2}\right.$, $200 \mathrm{ml}$ bicine) and density was determined using a $100 \mu \mathrm{m}$ deep Thoma haemocytometer (TH-100, Hecht-Assistent, Sondheim, Germany) at 400x magnification with phase contrast microscope (Olympus, Japan) expressing as spz. $\mathrm{x} 10^{9} / \mathrm{ml}$ (three replicates) (Y1ld1z et al. 2013).

\section{Storage of ovulated eggs}

A composition of three artificial mediums used for the in vitro storage of unfertilized scaly carp eggs is shown in Table 1. The final $\mathrm{pH}$ of each medium was regulated according to the natural $\mathrm{pH}$ of the coelomic fluid of scaly carp using $1.0 \mathrm{~N} \mathrm{HCl}$ and $1.0 \mathrm{~N} \mathrm{NaOH}$. In order to store eggs, a batch of 200 pooled eggs was gently placed in 
15-cm diameter petri dishes. The batches of eggs were washed with their storage mediums to eliminate coelomic fluid from the eggs. Petri dishes were filled with 20-ml of artificial mediums and
Ovarian fluid and then in vitro stored for durations of 30, 60 and $90 \mathrm{~min}$ prior to fertilization inside of sterile Laminar air flow cabinet at a constant temperature of $22.5^{\circ} \mathrm{C}$.

Table 1. Composition of the artificial mediums

\begin{tabular}{llc}
\hline $\begin{array}{l}\text { Artificial } \\
\text { Mediums }\end{array}$ & Composition & Reference \\
\hline $\begin{array}{l}\text { Ringer } \\
\text { Solution }\end{array}$ & $103 \mathrm{mM} \mathrm{NaCl}, 1 \mathrm{mM} \mathrm{KCl}, 1 \mathrm{mM} \mathrm{CaCl}, 1.1 \mathrm{mM} \mathrm{NaHCO}_{3}$ & (Linhart et al. 1991) \\
$\begin{array}{l}\text { Dettlaff } \\
\text { Solution }\end{array}$ & $111.3 \mathrm{mM} \mathrm{NaCl}, 3.3 \mathrm{mM} \mathrm{KCl}, 2.1 \mathrm{mM} \mathrm{CaCl}_{2}, 23.8 \mathrm{mM} \mathrm{NaHCO}_{3}$ & (Dettlaff et al. 1993) \\
$\begin{array}{l}\text { Cortland } \\
\text { Solution }\end{array}$ & $124 \mathrm{mM} \mathrm{NaCl}, 5.1 \mathrm{mM} \mathrm{KCl}, 1.0 \mathrm{mM} \mathrm{MgSO}_{4} .7 \mathrm{H} 2 \mathrm{O}, 1.6 \mathrm{mM} \mathrm{CaCl}_{2} .2 \mathrm{H}_{2} \mathrm{O}, 5.6 \mathrm{mM}$ glucose & (Wolf and Quimby \\
$\begin{array}{l}\text { Ovarian } \\
\text { Fluid }\end{array}$ & $741 \mathrm{mM} \mathrm{Na}^{+}, 0.45 \mathrm{mM} \mathrm{K}^{+}, 2.58 \mathrm{mM} \mathrm{Mg}^{2+}, 6.38 \mathrm{mM} \mathrm{Ca}^{2+}, 0.35 \mathrm{mM} \mathrm{Zn}^{2+}$ & 1969) \\
\hline
\end{tabular}

\section{Fertilization, eyeing and hatching of eggs}

Following 30, 60 and 90 min storage periods of unfertilized eggs, extenders and Ovarian fluids were removed from the petri dishes and $50 \mu \mathrm{l}$ sperm showing motility higher than $80 \%$ and containing roughly $2 \times 10^{5} \mathrm{spz}$. was added on to the eggs for the fertilization.

Fertilization process was performed in $100 \mathrm{ml}$ plastic container using activation solution containing $3 \mathrm{~g}$ urea and $4 \mathrm{~g} \mathrm{NaCl}$ in 11 distilled water at $24^{\circ} \mathrm{C}$ for five minutes through slow homogenization. Then, eggs were washed with water in order to eliminate adhesiveness and gently transferred to the labeled Zuger glass incubators with running water $\left(24^{\circ} \mathrm{C}\right)$ where kept until eyeing(14-16 h) and hatching(3-4 d).

Batches of eggs fertilized at the time of 0 (immediately after ovulation) served as a control group. Fertilization yield was determined at the gastrulation stage. The eyeing and hatching rate were defined as the number of eyed / hatched eggs divided by the initial number of eggs used for fertilization. Newly hatched larvaes were removed by siphoning and counted. Each treatment was performed in triplicate for each extender and storage period.

\section{Statistical analysis}

Differences between treatment groups were analyzed by repeated analysis of variance (one-way ANOVA). Significant means were subjected to a multiple comparison test (Duncan) for post-hoc comparisons at the level of $\alpha=0.05$. Results are presented as mean $\pm \mathrm{SE}$ and all analyses were carried out using SPSS 17 for Windows Statistical Software Package.

\section{Results}

Regarding the effect of storage periods on fertilization of eggs, the highest results were obtained as $71.33 \pm 9.45 \%, 82.00 \pm 4.00 \%$ and $68.00 \pm 4.00 \%$ in Dettlaff and Cortland solutions and Ovarian fluid respectively for 30,60 and $90 \mathrm{~min}$ storage periods (Figure 1). The overall meaning of the fertilizations were $64.83 \pm 7.74 \%, 65.5 \pm 11.69 \%$, and $60.67 \pm 8.52 \%$ respectively for 30,60 and $90 \mathrm{~min}$ storage periods that were significantly different $(\mathrm{p}<0.05)$ from $0 \mathrm{~min}$ control. Differences between mean fertilization rates within the same medium group were significant $(p<0.05)$ except for the Ovarian fluid when duration was considered.

The highest eyeing rate $(72.67 \pm 5.03 \%)$ was in eggs stored in Dettlaff solution for $30 \mathrm{~min}$ storage but Cortland solution was the best medium $(74.67 \pm 5.03 \%$ and $63.33 \pm 7.02 \%)$ for 60 and $90 \mathrm{~min}$ storage respectively (Figure 2). The overall meaning of the eyeings were $68.83 \pm 6.52 \%, 66.00 \pm 7.67 \%$, and $58.5 \pm 7.29 \%$ respectively for 30,60 and $90 \mathrm{~min}$ storage periods that were significantly different $(p<0.05)$ from 0 min control. Differences between mean eyeing rates within the same medium group were significant $(\mathrm{p}<0.05)$ when duration was considered.

In spite of obtaining the highest hatching rates $(56.00 \pm 4.00 \%$ and $47.33 \pm 5.03 \%)$ with the Ovarian fluid for $30 \mathrm{~min}$ and $60 \mathrm{~min}$ storage, the Cortland solution was $(43.33 \pm 4.16 \%)$ the best medium for 90 min storage (Figure 3). The overall meaning of the hatchings were $47.00 \pm 6.74 \%, 43.33 \pm 4.84 \%$, and $38.67 \pm 4.84 \%$ respectively for 30,60 and $90 \mathrm{~min}$ storage periods that were significantly different $(p<0.05)$ from 0 min control. Differences between mean hatching rates only for the Ovarian fluid group were significant $(\mathrm{p}<0.05)$ when duration was taken into consideration. 


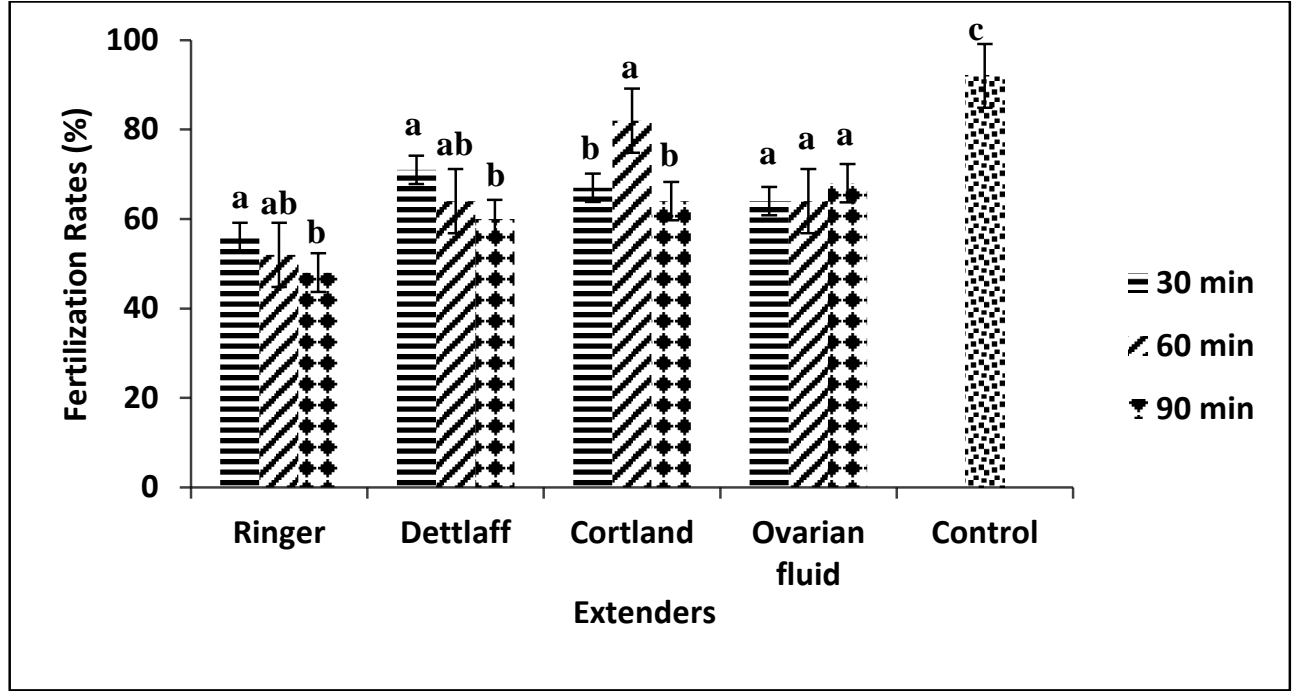

Figure 1. Fertilization rates of scaly carp eggs in vitro incubated in four different mediums for 0 (control), 30,60 and 90 min storage prior to fertilization.

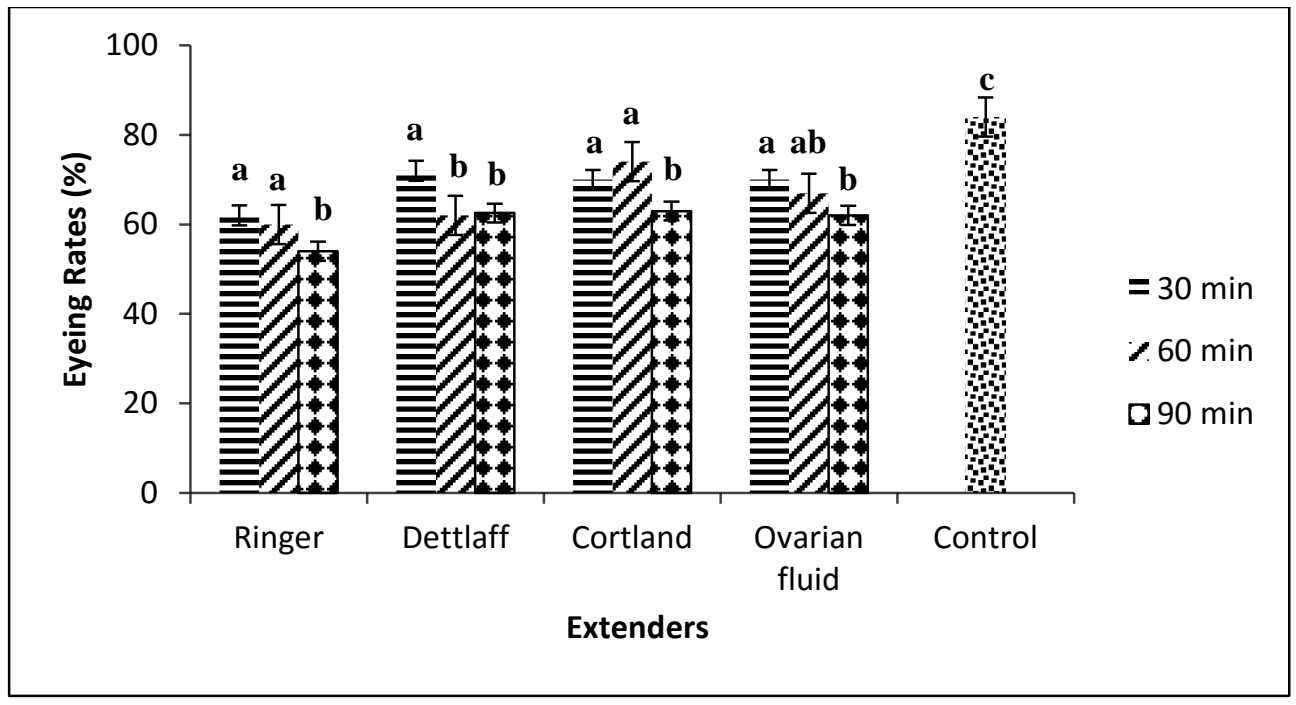

Figure 2. Eyeing rates of scaly carp eggs in vitro incubated in four different mediums for 0 (control), 30, 60 and 90 min storage prior to fertilization.

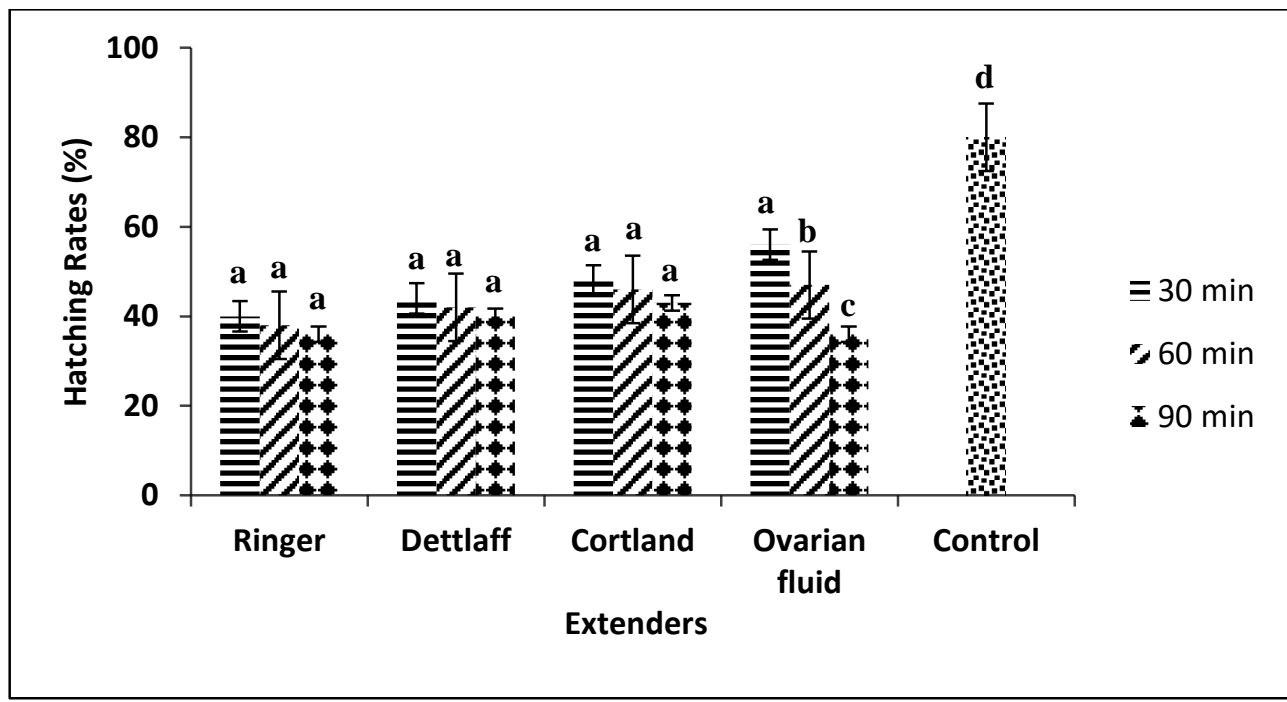

Figure 3. Hatching rates of scaly carp eggs in vitro incubated in four different mediums for 0 (control), 30, 60 and 90 min storage prior to fertilization. 


\section{Discussion}

In spite of cryopreservation of fish sperm developed with a satisfactory level, it has been less successful for the fish eggs due to the difficulty of removing intercellular water during the cooling process. Until now, only a few studies explored in vitro storage of fish eggs.

It is known that mature eggs can be kept for several days in Ovarian fluid and the storage duration is related to the holding temperature (Samarin et al. 2017; Ginatullina et al. 2018; Bozkurt and Yavaş 2012). For instance, Rothbard et al. (1996) reported that common carp (Cyprinus carpio) eggs can be stored for $6 \mathrm{~h}$ at a temperature range of $20^{\circ} \mathrm{C}-24.5^{\circ} \mathrm{C}$. Zlabek and Linhart (1987) compared in vitro storage of common carp (C. carpio), grass carp (Ctenopharyngodon idella) and silver carp, (Hypophthalmichthys molitrix) eggs at two temperature regimes $\left(3^{\circ} \mathrm{C}-5 \mathrm{C}^{\circ}\right.$ and $\left.14.5^{\circ} \mathrm{C}-18.0^{\circ} \mathrm{C}\right)$ and reported that common carp eggs exhibited better fertility and survivality of embryos than those of the Chinese carps.

On the other hand, Takano et al. (1973) reported that storing of eggs as in vitro in artificial mediums less effective for similar periods. According to Takano et al. (1973) chum salmon eggs could be stored for only one day in physiological saline. Similarly, Erdahl et al. (1987) indicated the possibility of short-term (5-10 $\mathrm{min})$ storage of unfertilized rainbow trout eggs in physiological saline solution without loss of fertility.

Most researchers have explored the development of eggs from fertility to eyeing stage (Erdahl et al. 1987; Lahnsteiner and Weismann 1999; Goetz and Coffman 2000). It is well known that less attention has been given to the survival of embryos from eyeing to the hatching stage following storage in different mediums for longer periods prior to fertilization. Researches have proven that carp eggs can be in vitro stored for several hours in Ovarian fluid outside of the body maintaining its viability and fertility (Rothbard et al. 1996). On the other hand, very few studies have explored in vitro preservation of carp eggs in different artificial mediums.

It is well known that eggs belong to fish species must be fertilized quickly following ovulation process otherwise lose their fertility quickly (Formacion et al. 1995). On the other hand, the present study demonstrated that scaly carp eggs can maintain their fertility when stored as in vitro in artificial mediums such as Ringer, Dettlaff, and Cortland solutions.

From this point of view, the present study demonstrated that ionic based solutions and Ovarian fluid can be used as artificial mediums for the preservation of scaly carp eggs up to $90 \mathrm{~min}$ at relatively high temperature $\left(22.5^{\circ} \mathrm{C}\right)$ under in vitro conditions. On the other hand, it is obvious that there is a decrease in terms of fertility, eyeing and hatchability of the eggs depending on period especially following $60 \mathrm{~min}$ storage in all cases except for Cortland solution.

The main reason for this increase in fertility at the end of the $60 \mathrm{~min}$ storage of the eggs in the Cortland solution and Ovarian fluid may be high sperm motility of fresh sperm cells. Results of the current study showed that the best fertilization and eyeing rates at each tested storage period were achieved when the eggs were treated with the Cortland solution. Similarly, Goetz and Coffman (2000) reported that unfertilized trout eggs can be maintained for at least two days without loss of fertility in modified Cortland solution buffered with Hepes or Tris. The present study also showed that while the eggs stored in Ovarian fluid showing the highest efficiency in term of hatching, the lowest one was the Ringer solution in all cases.

It should be known that the overall success of the conservation is highly depending on the extender composition, the origin of the broodfish and egg batch. Additionally, preservation of metabolic activity and maintaining of the viability of the eggs may be related to the health of the brood female, time of ovulation, incubation temperature and also the quality of hatchery water (Linhart and Billard 1995). From this point of view, the results of the current study showed that the survival of eggs in various treatments strongly depends on handling and management of spawners, temperature and egg quality prior to fertilization.

Furthermore, studies have indicated that bacterial infection might be one of the limiting factors in the preservation of fish eggs in artificial mediums and Ovarian fluid (Goetz and Coffman 2000; Niksirat et al. 2007). Hence, future studies should explore using of antioxidants and antibiotics to improve in vitro storage of eggs in scaly carp due to the positive effect of these substances in other fishes.

\section{Acknowledgements}

This research was supported by Scientific Research Projects Funds of Mustafa Kemal University (08-E-0210). The author would like to thank the staff of State Hydraulic Works Fish Production Station for their technical assistance in Adana, Turkey.

\section{References}

Bozkurt Y, Yavaş İ. 2012. Effect of temperatures and storage periods on fertilizing capacity of short-term preserved scaly carp (Cyprinus carpio) eggs. The Israeli Journal of Aquaculture-Bamidgeh. 64:680-685 
Carolsfeld J, Godinho HP, Zaniboni Filho E, Harvey BJ. 2003. Cryopreservation of sperm in Brazilian migratory fish conservation. $\mathrm{J}$ Fish Biol. 63(2):472-489. doi: 10.1046/j.1095-8649.2003.00170.x

Dettlaff TA, Ginsburg AS, Schmalhausen OI. 1993. Sturgeon fishes: developmental biology and aquaculture. Berlin: Springer-Verlag 299 p. doi: 10.1007/978-3-642-77057-9.

Erdahl AW, Cloud JG, Graham EF. 1987. Fertility of rainbow trout (Salmo gairdneri) gametes: gamete viability in artificial media. Aquaculture. 60(3-4):323-332. doi:10.1016/0044-8486(87)90297-3

Formacion MJ, Hori R, Lam TJ. 1993. Overripening of ovulated eggs in goldfish I. Morphological changes. Aquaculture. 114(1-2):155-168. doi: 10.1016/0044-8486(93)90258-Z

Formacion MJ, Venkatesh B, Tan CH, Lam TJ. 1995. Overripening of ovulated eggs in goldfish, Carassius auratus: II. Possible involvement of postovulatory follicles and steroids. Fish Physiol Biochem. 14(3):237-246. doi:10.1007/BF00004314

Ginatullina E, Komrakova M, Holtz W. 2018. Chilled storage of unfertilized and fertilized rainbow trout (Oncorhynchus mykiss) eggs in sealed polyethylene bags at different temperatures. Aquaculture. 484:214-218. doi: 10.1016/j.aquaculture.2017.11.028

Goetz FW, Coffman MA. 2000. Storage of unfertilized eggs of rainbow trout (Oncorhynchus mykiss) in artificial media. Aquaculture. 184(3-4):267-276. doi: 10.1016/S0044-8486(99)00327-0

Hobby AC, Pankhurst NW. 1997. Post-ovulatory egg viability in the snapper Pagrus auratus (Sparidae). Mar Freshwater Res. 48(5):385-389. doi: 10.1071/MF96120

Lahnsteiner F, Weismann T. 1999. Changes in eggs of brown trout, rainbow trout and grayling during shortterm storage. N Am J Aquacult. 61(3):213-219. doi: 10.1577/1548-8454(1999)061<0213:CIEOBT >2. $0 . \mathrm{CO} ; 2$

Linhart O, Barth T, Kouril J, Hamackova J. 1991. Stimulation of spermiation in tench (Tinca tinca L.) by analogues of GNRH and carp hypophysis. Paper presented at: $4^{\text {th }}$ International Symposium on Reproductive Physiology of Fish; Norwich, UK.

Linhart O, Billard R. 1995. Biology of gametes and artificial reproduction in common tench (Tinca tinca L.). A review. Polskie Arch Hydrobiol. 42(1-2):37-56.

Linhart O, Kudo S, Billard R, Slechta V, Mikodina EV. 1995. Morphology, composition and fertilization of carp eggs: a review. Aquaculture. 129(1-4):75-93. doi: 10.1016/0044-8486(94)00230-L

Niksirat H, Sarvi K, Mojazi Amiri B, Karami M, Hatef A. 2007. In vitro storage of unfertilized ova of endangered Caspian brown trout (Salmo trutta caspius) in artificial media. Anim Reprod Sci. 100(3-4):356-363.

doi: 10.1016/j.anireprosci.2006.08.019

Rothbard S, Rubinsthein I, Gelman E. 1996. Storage of common carp (Cyprinuscarpio L.) eggs for short durations. Aquac Res. 27(3):175-181. doi: 10.1111/j.1365-2109.1996.tb00982.x

Samarin AM, Żarski D, Palińska-Żarska K, Krejszeff S, Blecha M, Kucharczyk D, Policar T. 2017. In vitro storage of unfertilized eggs of the Eurasian perch and its effect on egg viability rates and the occurrence of larval malformations. Animal. 11(1):78-83. doi: $10.1017 / \mathrm{S} 1751731116001361$

Stoss J. 1983. 6 Fish gamete preservation and spermatozoan physiology. Fish Physiology. 9:305-350. doi: 10.1016/S1546-5098(08)60306-4

Suquet M, Chereguini O, Omnes MH, Rasines I, Normant Y, Souto IP, Quemener L. 1999. Effect of temperature, volume of ova batches, and addition of a diluent, an antibiotic, oxygen and a protein inhibitor on shortterm storage capacities of turbot, Psetta maxima, ova. Aquat Living Resour. 12(4):239-246. doi: 10.1016/S0990-7440(00)86634-6

Takano K, Hiroi O, Yasukawa M, Shetake T. 1973. Studies on the retention of gametes of salmonids fishes. I - On the fertility of chum salmon eggs after storage. Scientific Reports of the Hokkaido Salmon Hatchery. 27:31-37.

Tiersch TR. 2011. Process pathways for cryopreservation research, applications and commercialization. In: Tiersch TR, Green CC, editors. Cryopreservation in aquatic species, $2^{\text {nd }}$ edition. Baton Rouge: World Aquacult Society. p. 646-671.

Vuthiphandchai V, Zohar Y. (1999). Age-related sperm quality of captive striped bass Morone saxatilis. J World Aquacult Soc. 30(1):65-72. doi: 10.1111/j.1749-7345.1999.tb00318.x

Wolf K, Quimby MC. 1969. 5 Fish cell and tissue culture. Fish Physiology. 3:253-305. doi: 10.1016/S1546-5098(08)60115-6

Yıldız C, Bozkurt Y, Yavaş İ. (2013). An evaluation of soybean lecithin as an alternative to avian egg yolk in the cryopreservation of fish sperm. Cryobiology. 67(1):91-94. doi: 10.1016/j.cryobiol.2013.05.008

Zlabek A, Linhart O. 1987. Short-term storage of nonseminated and unfertilized eggs of the common carp, grass carp and silver carp. Bulletin VURH Vodnany. 23:3-11. 